\title{
THE COST OF INNOVATION: EVIDENCE FROM AUDITOR PRICING OF INVENTOR CHIEF EXECUTIVE OFFICERS
}

\author{
Dr. Ibrahim Bostan \\ Assistant Professor \\ College of Business Administration \\ Zayed University, United Arab Emirates \\ E-mail: Ibrahim.Bostan@zu.ac.ae \\ Dr. Yezen H. Kannan \\ Associate Professor \\ College of Business Administration \\ Zayed University, United Arab Emirates \\ E-mail: Yezen.Kannan@zu.ac.ae
}

\begin{abstract}
The study assesses whether auditors factor into their pricing of an audit engagement the presence of an inventor CEO given the potential conflict of interest this may present. Empirical and anecdotal evidence suggests that inventor CEOs may have more appetite for risk and may be less business-minded, thus suggesting potential agency costs for the firm. We rely on a self-developed database of inventor CEOs and archival data from other sources. Using multivariate regressions, we assess the association between the presence of an inventor $\mathrm{CEO}$ and audit fees, while controlling for audit fee determinants. The results of our analysis reveal that auditors assess a fee premium in the presence of inventor CEOs. Additional analysis also finds that this fee premium is not exacerbated by the presence of audit risk, and the engagement of top-tier auditors significantly reduces auditor pricing of the presence of an inventor CEO. Our analysis also shows that the positive and significant association between audit fees and the presence of an inventor CEO is significantly stronger in the presence of greater financial distress. Overall, our findings suggest that auditors factor into their pricing decision the potential conflict of interest between CEO inventor managers and shareholders.
\end{abstract}

Keywords: Auditing, Inventor CEO, R\&D.

JEL Classification Codes: M42, J2, O32.

\section{INTRODUCTION}

Having an inventor heading the firm's management team (hereafter inventor CEO) is common practice, especially among high technology industries including the five Big Tech companies (Amazon, Facebook, Apple, Google, and Microsoft) many Fortune 500 firms have inventor CEOs (Amazon, Google, Oracle, Apple). The recent work shows that inventor CEO firms produce more innovations, and these innovations are more impactful. Compared to other firms, inventor CEO firms generate more breakthrough patents that receive more recognition in their technological fields. This evidence indicates that even in this risky research and development environment inventor CEOs pursue even riskier endeavors. Despite their 
prevalence and influence, the academic studies investigating the impact of inventor CEOs from different business perspectives are limited. An important question that has yet to be assessed is whether auditor's factor in the potential risks embedded in firms with inventor CEOs and whether this is a priced risk factor.

While having technically superior knowledge of their field, inventor CEOs might have "tunnel vision" focusing on a very specialized are, which could prevent them from looking at investments from a broader business perspective. Anecdotal evidence suggests that a divide between inventors and firm management is healthy. For example, Scott Keeley, a patent agent, compares two start-up firms, one run by an inventor and the other by a non-inventor. The start-up that was managed by the inventor (with no business background) failed, whereas the start-up that was run by a business-minded founder succeeded. Keely attributes the success of the start-up run by a business-minded person to the fact that this start-up allowed "the business-person of their team to handle management, and the inventor to create". Further, Kerr, Kerr, and Dalton (2019) find that entrepreneurs' financial risk appetite is $41 \%$ greater than noninventor employees and the tolerance of this risk by inventor employees is $16 \%$ greater than non-inventor employees ${ }^{i}$. Therefore, it is an unexplored empirical question of whether these characteristics of Inventor CEOs result in higher or lower fee structure by auditing firms.

In this paper, we assess the audit auditor pricing decision of innovative management, using a measure of the CEO's innovative ability through patents granted to his/her name. We further assess whether this pricing decision is attributed to audit risk, the mitigating role of governance on this pricing decision, and the influence that financial distress has on the association between audit fees and the presence of CEO inventors. Our multivariate analysis, which regresses audit fees on the presence of an inventor CEO, while controlling for audit fee determinants, finds evidence to suggest that auditors assess a fee premium in the presence of inventor CEOs, and this fee premium is not exacerbated by the presence of audit risk. We also find evidence to suggest that the engagement of top-tier auditors significantly reduces auditor pricing of firms with inventor CEOs. Finally, we find that this association is significantly stronger in the presence of greater financial distress.

Our paper contributes to and combines two distinct research streams; 1. The audit fee/risk literature; 2 . The innovation literature and assesses the potential risks embedded in innovation-driven CEOs. Our findings inform corporate stakeholders (investors, creditors, suppliers, customers, employees,) of the potential risks from managerial pursuits of patents. Also, while most audit fee papers focus on firm risk when assessing a fee premium, we focus on CEO personal traits and the potential risk attributes inventor CEOs may possess to assess the presence of a fee premium. In doing so, we also contribute to the Upper Echelons theory, which suggests that executive traits, background, and experiences shape the choices they make (Hambrick \& Mason, 1984; Hitt \& Ireland, 1985), and the potential risks embedded in their choices. Furthermore, we also add to the growing literature on the importance of CEO characteristics on corporate innovation outcomes, highlighting the potential tradeoffs that firms make in their hiring decision. One cost that has not been addressed in the literature is the audit costs from the presence of an inventor CEO.

The paper proceeds as follows. In section 2, we review related literature and develop our research question. In section 3, we discuss our methodological approach, data and present descriptive statistics. Section 4 presents our multivariate results and section 5 provides additional tests and analysis. Section 6 then presents the discussion of our findings and conclusions.

\section{Innovative CEOs and Risk}

\section{LITERATURE REVIEW AND HYPOTHESES DEVELOPMENT}

In a world of constant change and advancement, corporate climates need to swiftly adapt and innovate to retain their market shares, especially in highly competitive industries. The current global pandemic 
environment is proof of how innovative and adaptive firms were able to quickly adapt to the unusual circumstances and prospered when many other companies and industries suffered tremendous losses and even declared bankruptcy. Top management is the focal force of initiating and driving this innovation. Many studies in the literature have examined top management's impact on firm performance, arguing that top managers are paramount to firm success (Hambrick \& Mason 1984; March \& Simon 1958). Firm leadership, as delegators of shareholders, have their own set of beliefs on how to sustain and grow firm performance, and these beliefs shape their investment decisions.

Prior literature identifies a link between CEO investment in innovative pursuits and firm performance. The experience attained by these CEOs through their innovation experience may provide them with unique insights that can assist them and their firms in evaluating, selecting, and successfully executing investment projects. This hands-on experience has been linked to the quality of decisionmaking (Bradley, Gokkaya, \& Liu 2017; Cai, Sevilir, \& Tian 2012; Shah \& Tripas, 2007, Laursen, 2011). Benabou and Tirole (2003) analyze the principal-agent relationship from an extrinsic-intrinsic motivation perspective arguing that a risk-averse executive might be more inclined to focus on short-term goals rather than focusing on long-term $\mathrm{R} \& \mathrm{D}$ investments, and therefore obtaining greater personal gains. They suggest that an inventor executive, in contrast, will focus on innovation for its own sake owing to intrinsic motivation, rather than an extrinsic personal gains motive. Furthermore, an inventor executive may be better suited to evaluate the feasibility, attractiveness, and potential success of certain investment pursuits given their innovative experience. Consistent with this notion, Islam and Zein (2020) and Bostan and Mian (2019) both find that firms led by inventor CEOs are associated with a greater number of patents and higher quality patents at the firm level.

Successful innovative initiatives and pursuits by managers lead to enhanced firm performance, growth, and survival. However, these efforts are riddled with uncertainties and risks. The nature of hightechnology environments (e.g. R\&D intensive firms) in their constant pursuit of innovative breakthroughs is linked to greater outcome uncertainty. Bostan and Mian (2019) find that inventor CEOs undertake riskier innovations resulting in more failures. They also find that inventor CEO firms are more likely to pursue explorative innovations, relying on a wider set of technological classes and departing significantly from the technological areas which are known to the firm, thus exacerbating risks and uncertainties.

Adding to the risk-seeking behavior of inventor CEOs is the "sensation seeking behavior" (Sunder, Sunder, \& Zhang, 2017). The combination of intrinsic motivation to pursue new ideas (He \& Hirshleifer, 2019) and strong "sensation-seeking" behavior (Sunder et al., 2017) can create agency problems between the inventor CEO and shareholders, "as the marginal utility from investing in corporate innovation may be higher for managers than for shareholders" (Byun, Fuller, \& Lin, 2020). Byun et al, (2020) find that inventor CEOs over-invest in research and development, hold excess cash associated with lower marginal value, and are reluctant to use financial leverage. They also find that inventor CEOs are not granted a compensation premium in the labor market, suggesting that their benefits are mitigated by added agency costs.

Furthermore, inventor CEOs may be better suited at identifying innovative ideas related to their area of expertise than non-inventor CEOs, this does not guarantee that they are better suited at managing the innovative pursuits and achieving success. They may also be reluctant to accept ideas from other members of the management team in areas outside their domain. Anecdotal evidence suggests that inventors may not be the best to commercialize and market the idea, and therefore may not be the most qualified to lead start-ups that revolve around their invention. Case in point, the MIT Centre for Entrepreneurship has made it mandatory that an inventor cannot be the spin off's founding CEO ${ }^{\mathrm{ii}}$. Consistent with this anecdotal evidence, Islam and Zein (2019) finds that only 19\% of their sample of tech industry CEOs have innovation experience, and Baranchuk, Kieschnick, and Moussawi (2014) find 
that only $28 \%$ of their sample firm have CEOs with technical degrees. This suggests that there are costs to hiring inventor CEOs.

\section{Auditor Pricing of Innovation}

A growing body of audit literature investigates the association between CEO traits (age, gender, education) and accounting outcomes. Furthermore, the literature also assesses auditors' pricing response to CEO characteristics that could affect audit engagement risk (either audit risk or business risk). This literature finds evidence to suggest that auditors perceive greater risk, as evidenced by higher audit fees, in the presence of CEO equity incentives (Kannan, Skantz, \& Higgs, 2015; Kim, Li, \& Li, 2015; Wysocki, 2010), CEO overconfidence (Hribar, Kim, Wilson, \& Yeng, 2012), CEO narcissism (Johnson, Kuhn, Apostolou, \& Hassell, 2012, Judd, Olsen, \& Stekelberg, 2015), and CEO gender (Huang, Huang, \& Lee, 2014). On the other hand, auditors perceive that the presence of a financial expert $\mathrm{CEO}^{\mathrm{iii}}$ reduces engagement risk and audit fees.

A key CEO feature that has not been explored in the audit literature is whether and how auditors assess the presence of an inventor CEO in the audit engagement. On the one hand, inventor CEOs with hands-on experience may have a better ability at identifying investments and have enough experience to successfully implement and gain from these investments. Furthermore, these CEOs may better appreciate the benefits and needs of investing in $R \& D$, despite the potential short-term costs to the firm and self, suggesting a reduction in agency conflicts between these managers and shareholders. This would suggest a reduction in engagement risk from the auditors' perspective.

On the other hand, inventor CEOs may be "sensation-seeking", unable to commercialize firm inventions, and may over-invest in $\mathrm{R} \& \mathrm{D}$, all of which may be detrimental to the firm and its shareholders. Furthermore, inventor CEOs may be more inclined to pursue risky projects with high failure rates given their past experiences and successes. This could also be detrimental to the firms' ability to meet their obligations and even worse could lead to corporate failure. From the perspective of the auditor, if they believe that inventor CEOs are pursuing risky, ambitious projects with high failure rates, then auditors may factor into the pricing of the engagement a fee premium for the added risks (relative to firms in the same industry that are not pursuing risky innovative strategies).

Auditors charge higher fees in the presence of greater audit and business risk resulting from the audit engagement (see Hay, Knechel, \& Wong, 2006 for a review of the literature). The Simunic (1980) audit fee model suggests that auditors are compensated for conducting the audit per se (Walo, 1995; Zimbelman, 1997; Glover, Jiambalvo, \& Kennedy, 2000; Glover, Prawitt, Schultz, \& Zimbelman, 2003; Gul, Chen, \& Tsui, 2003; Bedard \& Johnstone, 2004; Dickins, Higgs, \& Skantz, 2008), to provide insurance for investor losses, and to insure against risks associated with factors that extend beyond the conduct of the audit, including litigation ${ }^{\text {iv }}$. The auditors may reduce risks associated with factors outside the conduct of the audit (such as litigation) with additional audit scope and through their client acceptance practice. However, some of these risk factors can't be audited away (Bell, Landsman, \& Shackelford, 2001). Given this risk, auditor's price business risk based on potential costs from audit client shareholder lawsuits, reputational damage due to their association with the client, and declining client performance (Houston et al., 2005). This is accomplished by charging a fee premium to compensate for business risk (Stanley, 2011; Lyon \& Maher, 2005; Bell et al., 2001).

In sum, inventor CEOs may enhance their firm's performance and allow the firm to sustain or even expand on their market share within certain industries due to their constant pursuit of groundbreaking inventions. From an auditor's perspective, and if the firm is in a position to pursue these investment projects with a low likelihood of firm default, the auditor may reward them as a result of lower business risks, suggesting a lower audit fee. On the other hand, if inventor CEOs are pursuing innovative 
initiatives despite the high risks involved and the lack of firm resources to pursue them, and through the access of high-cost funding sources, this could result in an added level of business risk for the client and the auditor.

Given the counter-arguments, we present our first research question as follows:

\section{Research question 1. Do auditors charge a fee premium for audit clients with inventor CEOs?}

\section{Data}

\section{DATA, METHODOLOGY, AND DESCRIPTIVE STATISTICS}

Several databases were combined to conduct this study. Standard and Poor's Execucomp database is the main database, supplemented with other databases. Execucomp is used to obtain information on corporate CEOs, such as full name, age, and tenure. Execucomp is merged with the Inventor Database created by $\mathrm{Li}$ et al. (2014) to obtain information about the executives' innovation activity. The inventor database identifies more than two million unique inventors to whom approximately 3.8 million patents have been granted by United States Patents and Trademark Office. The challenge is that two databases do not have a common identifier. Hence, using names of inventors and CEOs in a fuzzy match algorithm we obtained similarities of names and manually confirmed the matches through additional information on both databases, such as company affiliation. Wherever required we refer to other sources to make sure that the matches are correct. These further resources include (but are not limited to) company websites, LinkedIn, Bloomberg, NNDB, TWST, SEC forms, and other online sources.

Financial statement data is obtained from Standard and Poor's Compustat database. Audit fees, auditor size, financial statement restatements, and auditor tenure are from Audit Analytics; institutional ownership data is from Compact D/SEC; stock return data is from the Center for Research in Security Prices (CRSP). Further, we exclude financial institutions. Our final sample with all necessary regression model variables is 6,667 non-financial firm-year observations covering the period 2000-2008.

\section{Methodology}

We use a pooled ordinary least squares (OLS) regression model to estimate the audit fee model which includes proxies for audit effort and their risk exposure, as the literature identifies. ${ }^{\mathrm{N}}$ We include industry and year fixed effects in all analysis and cluster by firm (GVKEY) and year to eliminate autocorrelations, as suggested by Peterson (2009). The equation used to test our first research question is as follows:

$$
\begin{aligned}
& \operatorname{LnAF}_{i, t}=\alpha_{0}+\alpha_{1}\left(\text { CEO_INVENT }_{i, t}\right)+\alpha_{2}\left(\text { LNTA }_{i, t}\right)+\alpha_{3}\left(\text { FOROPS }_{i, t}\right)+\alpha_{4}\left(\text { XDOPS }_{i, t}\right)+\alpha_{5}\left(\text { INVREC }_{i, t}\right)+ \\
& \alpha_{6}\left(L A G_{i, t}\right)+\alpha_{7}\left(\operatorname{LOSS}_{i, t}\right)+\alpha_{8}\left(\operatorname{ROA}_{i, t}\right)+\alpha_{9}\left(L I Q_{i, t}\right)+\alpha_{10}\left(L E V_{i, t}\right)+\alpha_{11}\left(\operatorname{MTB}_{i, t}\right)+\alpha_{12}\left(B U S Y_{i, t}\right)+\alpha_{13}\left(I_{i, t-1}\right) \\
& +\alpha_{14}\left(\text { BIGN }_{i, t}\right)+\alpha_{15}\left(\text { SWITCH }_{i, t}\right)+\alpha_{16}\left(\text { RESTATE }_{i, t}\right)+\alpha_{17}\left(G_{i, t}\right)+\alpha_{18}\left(\text { ICWEAK }_{i, t}\right)+\alpha_{19}\left(\text { ICFR }_{i, t}\right)+\sum \text { Year } \\
& +\sum \text { Industry }+e_{i, t}
\end{aligned}
$$

Where

$\operatorname{LnAF} \quad=$ the natural $\log$ of audit fees at fiscal year-end, from the Audit Analytics database

CEO_INVENT = A dummy variable that identifies the CEOs who have at least one patent filed during the sample period.

See Appendix A for variable definitions. 


\section{Descriptive Statistics}

Table 1. Distribution of Sample

Panel A of Table 1 provides the yearly distribution of observations used in the main analysis for the full sample and Inventor CEO sample. Panel B of Table 1 breakdowns the observations by industry groups for both the total sample and inventor CEO sample.

Panel A. Year Distribution

\begin{tabular}{|l|c|c|c|}
\hline Year & Total & CEO_INVENT=1 & Percent \\
\hline 2000 & 552 & 57 & $10.33 \%$ \\
\hline 2001 & 688 & 62 & $9.01 \%$ \\
\hline 2002 & 697 & 60 & $8.61 \%$ \\
\hline 2003 & 731 & 60 & $8.21 \%$ \\
\hline 2004 & 747 & 54 & $7.23 \%$ \\
\hline 2005 & 734 & 47 & $6.40 \%$ \\
\hline 2006 & 774 & 46 & $5.94 \%$ \\
\hline 2007 & 882 & 68 & $7.71 \%$ \\
\hline 2008 & 862 & 65 & $7.54 \%$ \\
\hline Total & 6,667 & 519 & $7.78 \%$ \\
\hline
\end{tabular}

Panel B: Industry Distribution

\begin{tabular}{|l|c|c|c|}
\hline Industry & Total & CEO_INVENT=1 & Percent \\
\hline Aircraft & 91 & 8 & $8.79 \%$ \\
\hline Almost nothing & 128 & 9 & 7.03 \\
\hline Apparel & 115 & 13 & $11.30 \%$ \\
\hline Automotive \& trucks & 166 & 13 & $7.83 \%$ \\
\hline Business Service & 1,088 & 31 & $2.85 \%$ \\
\hline Business Supply & 189 & 3 & $1.59 \%$ \\
\hline Chemical & 305 & 12 & $3.93 \%$ \\
\hline Communication & 258 & 11 & $4.26 \%$ \\
\hline Computer & 422 & 40 & $9.48 \%$ \\
\hline Construction Materials & 225 & 15 & $6.67 \%$ \\
\hline Consumer goods & 202 & 8 & $3.96 \%$ \\
\hline Defense & 47 & 12 & $25.53 \%$ \\
\hline Electrical Equipment & 126 & 15 & $11.90 \%$ \\
\hline Electronic Equipment & 755 & 151 & $20.00 \%$ \\
\hline Entertainment & 77 & 11 & $14.29 \%$ \\
\hline Food products & 154 & 1 & $0.65 \%$ \\
\hline Machinery & 397 & 62 & $15.62 \%$ \\
\hline Measuring and & 276 & 20 & $7.25 \%$ \\
\hline Medical & 338 & 22 & $6.51 \%$ \\
\hline Personal Service & 113 & 2 & $1.77 \%$ \\
\hline Pharmaceutical & 486 & 30 & $6.17 \%$ \\
\hline Recreation & 70 & 10 & $14.29 \%$ \\
\hline Retail & 214 & 13 & $6.07 \%$ \\
\hline
\end{tabular}




\begin{tabular}{|l|c|c|c|}
\hline Trading & 82 & 4 & $4.88 \%$ \\
\hline Wholesale & 343 & 3 & $0.87 \%$ \\
\hline Total & 6,667 & 519 & $7.78 \%$ \\
\hline
\end{tabular}

According to Table 1, Panel A, we notice a steady decline in the percentage of inventor CEOs from 2000-2006 (10.33\%-5.94\%). On average and across the sample period, the overall percentage of CEO inventors $(519)$ to the total sample $(6,667)$ is 7.78 percent.

Table 1, Panel B presents the industry distribution of our sample and the subsample of inventor CEOs. We rely on the Fama, French 48 industry classifications. The industries with the highest proportion of inventor CEOs are defense (25.53\%), Electronic equipment (20.00\%), and Machinery (15.62\%). Industries with the lowest proportions are Food Production $(0.65 \%)$ and Wholesale $(0.87 \%)$.

Table 2 provides the descriptive statistics for all variables included in our regression analyses. All continuous variables are winsorized at the $1^{\text {st }}$ and $99^{\text {th }}$ percentiles.

Table 2. Descriptive Statistics

\begin{tabular}{|l|l|l|l|l|l|l|}
\hline Variables & $\mathrm{N}$ & Mean & Median & Std. Dev. & $\mathrm{Q} 1$ & $\mathrm{Q} 3$ \\
\hline LnAF & 6,667 & 14.018 & 13.997 & 1.201 & 13.208 & 14.817 \\
\hline CEO_INVENT & 6,667 & 0.077 & 0.000 & 0.267 & 0.000 & 0.000 \\
\hline LnTA & 6,667 & 13.949 & 13.757 & 1.594 & 12.860 & 14.927 \\
\hline FOROPS & 6,667 & 0.338 & 0.000 & 0.473 & 0.000 & 1.000 \\
\hline XDOPS & 6,667 & 0.265 & 0.000 & 0.441 & 0.000 & 1.000 \\
\hline INVREC & 6,667 & 0.265 & 0.250 & 0.155 & 0.146 & 0.354 \\
\hline LAG & 6,667 & 40.340 & 37.000 & 16.570 & 29.000 & 49.000 \\
\hline LOSS & 6,667 & 0.237 & 0.000 & 0.425 & 0.000 & 0.000 \\
\hline ROA & 6,667 & 0.081 & 0.088 & 0.112 & 0.040 & 0.137 \\
\hline LIQ & 6,667 & 2.750 & 2.071 & 2.074 & 1.437 & 3.218 \\
\hline LEV & 6,667 & 0.169 & 0.135 & 0.178 & 0.000 & 0.271 \\
\hline MTB & 6,667 & 2.137 & 1.701 & 1.400 & 1.262 & 2.481 \\
\hline BUSY & 6,667 & 0.759 & 1.000 & 0.427 & 1.000 & 1.000 \\
\hline IO & 6,667 & 0.729 & 0.762 & 0.218 & 0.602 & 0.877 \\
\hline BIGN & 6,667 & 0.934 & 1.000 & 0.246 & 1.000 & 1.000 \\
\hline SWITCH & 6,667 & 0.146 & 0.000 & 0.353 & 0.000 & 0.000 \\
\hline RESTATE & 6,667 & 0.036 & 0.000 & 0.186 & 0.000 & 0.000 \\
\hline GC & 6,667 & 0.012 & 0.000 & 0.111 & 0.000 & 0.000 \\
\hline ICWEAK & 6,667 & 0.048 & 0.000 & 0.215 & 0.000 & 0.000 \\
\hline ICFR & 6,667 & 0.558 & 1.000 & 0.496 & 0.000 & 1.000 \\
\hline
\end{tabular}

Variable definitions are presented in Appendix A

The mean (median) of our dependent variable, the natural $\log$ of audit fees $(L n A F)$ is 14.018 (13.997), corresponding to mean (median) dollar values of \$2.51 (\$1.20) million. Our treatment variable is the presence of an inventor CEO (CEO_INVENT). Consistent with Table 1 findings above, the proportion of firm-year observations with inventor CEOs is $7.7 \%$.

Descriptive statistics for audit fee determinants are presented next in Table 2. The mean (median) natural $\log$ of total assets $(\ln T A)$ is $13.949(13.765)$; this corresponds to a dollar value of $\$ 4.409(\$ 0.43)$ in billions of U.S dollars. The mean (median) proportion of inventory and receivables to total assets is 
26.5 percent (25.0 percent) and the mean (median) ratio of current assets to current liabilities (LIQ) is 2.750 (2.071). Further, the mean (median) sample leverage ( $L E V)$, calculated as total debt to total assets, is $0.169(0.135)$, the average return on assets $(R O A)$ is 8.1 percent, market to book ratio (MTB) is 2.13 , and the number of days between earnings announcement day and fiscal year-end ( $L A G)$ is 40.34 days.

Approximately 33.8 of our sample have foreign operations (FOROPS), 23.7\% reported annual losses in their financials $(L O S S)$ and $75.9 \%$ had a December 31 fiscal year-end (BUSY). Regarding audit engagement attributes, $93.4 \%$ of the sample engaged a top-tier auditor $(B I G N)$ and $14.6 \%$ switched auditors during the period of the study $($ SWITCH). Further, $1.2 \%$ were issued a modified going concern opinion $(G C), 3.6 \%$ were required to restate their financial statements (RESTATE), $4.8 \%$ were assessed an internal control weakness over financial reporting by their auditor (ICWEAK).

\section{Univariate Analysis}

\section{RESULTS}

In Table 3, we present our univariate analysis. We conduct a test of mean differences between a sample of CEO inventor firms and non-CEO inventor firms.

Table 3. Univariate Analysis

\begin{tabular}{|l|c|c|c|c|}
\hline & CEO_INVENT=0 & CEO_INVENT=1 & Difference & T-statistics \\
\hline Variables & $\mathrm{N}=6,184$ & $\mathrm{~N}=519$ & & \\
\hline LnAF & 14.048 & 13.663 & 0.384 & $7.03^{* * *}$ \\
\hline LnTA & 13.993 & 13.434 & 0.558 & $7.70^{* * *}$ \\
\hline FOROPS & 0.339 & 0.331 & 0.007 & 0.36 \\
\hline XDOPS & 0.274 & 0.158 & 0.116 & $5.78^{* * *}$ \\
\hline INVREC & 0.268 & 0.234 & 0.034 & $4.78^{* * *}$ \\
\hline LAG & 40.436 & 39.206 & 1.230 & 1.62 \\
\hline LOSS & 0.231 & 0.312 & -0.082 & $-4.18^{* * *}$ \\
\hline ROA & 0.083 & 0.055 & 0.028 & $5.50^{* * *}$ \\
\hline LIQ & 2.642 & 4.030 & -1.388 & $-14.88^{* * *}$ \\
\hline LEV & 0.173 & 0.125 & 0.048 & $5.94^{* * *}$ \\
\hline MTB & 2.104 & 2.526 & -0.421 & $-6.60^{* * *}$ \\
\hline BUSY & 0.758 & 0.768 & -0.010 & -0.53 \\
\hline IO & 0.733 & 0.681 & 0.051 & $5.18^{* * *}$ \\
\hline BIGN & 0.937 & 0.901 & 0.036 & $3.19^{* * *}$ \\
\hline SWITCH & 0.147 & 0.140 & 0.006 & 0.39 \\
\hline RESTATE & 0.036 & 0.036 & -0.000 & -0.06 \\
\hline GC & 0.011 & 0.027 & -0.015 & $-3.06^{* * *}$ \\
\hline ICWEAK & 0.049 & 0.038 & 0.010 & 1.11 \\
\hline ICFR & 0.563 & 0.506 & 0.056 & $2.49^{* *}$ \\
\hline
\end{tabular}

$*, * *$, and $* * *$ denote significance at $10 \%, 5 \%$, and $1 \%$ levels, respectively. The definitions of all the variables are provided in Appendix A.

According to Table 3 findings, we notice that CEO inventor firms, relative to non-CEO inventor firms, have significantly less total assets $(L n T A)$, extraordinary items disclosed in their financial reports $(X D O P S)$, leverage $(L E V)$, institutional ownership $(I O)$, return on assets $(R O A)$, and less likely to engage a top tier auditor $(B I G N)$. On the other hand, CEO inventor firms disclose significantly greater losses 
(LOSS), are more liquid ( $L I Q)$, are more likely to receive modified going concern opinion by the auditor $(G C)$, and have a greater market to book ratio $(M T B)$.

Furthermore, we find that the subsample of CEO inventor firms is charged significantly lower audit fees $(L n A F)$ relative to their non-CEO inventor firms, however, this finding could be attributed to the finding above that non-inventor CEO firms are significantly larger than inventor CEO firms. In untabulated analysis, and after scaling total fees by total assets, we find that the size adjusted audit fees for the inventor CEO subgroup is greater than that for the non-inventor CEO subgroup ( $(p \text {-value }<0.01)^{v i}$. This finding provides preliminary evidence for research question 1.

\section{Multivariate Analysis \\ Research Question 1}

We begin with our multivariate results concerning our tests of research question 1 (Do auditors charge a fee premium for audit clients with inventor CEOs?). To do so, we regress the natural log of audit fees (our dependent variable) on a dichotomous variable equal to 1 if the firm CEO has been successfully granted a patent, and 0 otherwise, while controlling for audit fee determinants. This analysis testing research question 1 is shown in Table 4 . We present all analyses with clustered standard errors at the firm-year level to address potential cross-sectional correlation of error terms (Peterson, 2009), and also include year and industry controls to address macroeconomic and time-period effects.

Table 4. Inventor CEOs and Audit Fees

\begin{tabular}{|c|c|c|}
\hline & \multicolumn{2}{|c|}{ Dependent Variable $=\operatorname{Ln} A F$} \\
\hline & Baseline Model & \\
\hline \multirow[t]{3}{*}{ Variables } & Model (1) & Model (2) \\
\hline & Coefficient & Coefficient \\
\hline & (t-statistics) & (t-statistics) \\
\hline \multirow[t]{2}{*}{ CEO_INVENT } & & 0.078 \\
\hline & & $(3.12)^{* * *}$ \\
\hline LNTA & $\begin{array}{c}0.568 \\
(90.75)^{* * *}\end{array}$ & $\begin{array}{c}0.568 \\
(90.82)^{* * * *}\end{array}$ \\
\hline FOROPS & $\begin{array}{c}0.178 \\
(12.28)^{* * *}\end{array}$ & $\begin{array}{c}0.178 \\
(12.29)^{* * *}\end{array}$ \\
\hline$X D O P S$ & $\begin{array}{c}0.143 \\
(9.00)^{* * *}\end{array}$ & $\begin{array}{c}0.146 \\
(9.14)^{* * *}\end{array}$ \\
\hline INVREC & $\begin{array}{c}0.595 \\
(9.93)^{* * *}\end{array}$ & $\begin{array}{c}0.602 \\
(10.06)^{* * *}\end{array}$ \\
\hline \multirow[t]{2}{*}{$L A G$} & 0.006 & 0.006 \\
\hline & $(10.44)^{* * *}$ & $(10.43) * * *$ \\
\hline \multirow[t]{2}{*}{ LOSS } & 0.077 & 0.076 \\
\hline & $(3.52)^{* * *}$ & $(3.51)^{* * *}$ \\
\hline \multirow[t]{2}{*}{$R O A$} & -0.437 & -0.427 \\
\hline & $(-4.26) * * *$ & $(-4.15)^{* * *}$ \\
\hline \multirow[t]{2}{*}{$L I Q$} & -0.059 & -0.060 \\
\hline & $(-14.50)^{* * *}$ & $(-14.67)^{* * *}$ \\
\hline \multirow[t]{2}{*}{$L E V$} & -0.119 & -0.115 \\
\hline & $(-2.46) * *$ & $(-2.38)^{* *}$ \\
\hline$M T B$ & 0.008 & 0.007 \\
\hline
\end{tabular}




\begin{tabular}{|c|c|c|}
\hline & $(1.28)$ & (1.08) \\
\hline \multirow[t]{2}{*}{$B U S Y$} & 0.061 & 0.060 \\
\hline & $(3.73)^{* * *}$ & $(3.66)^{* * *}$ \\
\hline \multirow[t]{2}{*}{$I O$} & -0.063 & -0.059 \\
\hline & $(-1.58)$ & $(-1.49)$ \\
\hline \multirow[t]{2}{*}{$B I G N$} & 0.103 & 0.104 \\
\hline & $(3.31)^{* * *}$ & $(3.36) * * *$ \\
\hline \multirow[t]{2}{*}{ SWITCH } & -0.017 & -0.015 \\
\hline & $(-0.64)$ & $(-0.56)$ \\
\hline \multirow[t]{2}{*}{ RESTATE } & 0.195 & 0.193 \\
\hline & $(4.95) * * *$ & $(4.91) * * *$ \\
\hline \multirow[t]{2}{*}{$G C$} & 0.055 & 0.001 \\
\hline & $(0.06)$ & $(0.02)$ \\
\hline \multirow[t]{2}{*}{ ICWEAK } & 0.288 & 0.290 \\
\hline & $(6.93)^{* * *}$ & $(6.97) * * *$ \\
\hline \multirow[t]{2}{*}{$I C F R$} & 0.374 & 0.371 \\
\hline & $(8.50)^{* * *}$ & $(8.45) * * *$ \\
\hline \multirow[t]{2}{*}{ Constant } & 4.612 & 4.606 \\
\hline & $(37.99)^{* * *}$ & $(37.95) * * *$ \\
\hline Industry FE & YES & YES \\
\hline Year FE & YES & YES \\
\hline Observations & 6,667 & 6,667 \\
\hline R-squared & $79.41 \%$ & $79.43 \%$ \\
\hline Model & $584.10 * * *$ & $571.99 * * *$ \\
\hline
\end{tabular}

$*, * *$, and $* * *$ measure significance at the $10 \%, 5 \%$, and $1 \%$ levels, respectively. All regressions include year and industry fixed effects. Standard errors are robust and clustered at the firm and year levels (Peterson, 2009). The definitions of all variables are provided in Appendix A.

Consistent with prior research on audit fee determinants, in Model 1 we find that auditors assign a significantly higher audit fee with greater firm size (LnTA), inherent risk (INVREC), and complexity, measured using the presence of foreign operations (FOROPS), the presence of extraordinary items $(X D O P S)$ and the number of days between fiscal year-end and earnings announcement date (LAG), all at $p$-value $<0.01$. We also find that audits conducted during busy season (BUSY) are assigned significantly higher fees $(p$-value < 0.01$)$ and greater firm liquidity $(L I Q)$ is associated with lower audit fees $(p$-value $<0.01)$. Counter to prior literature, we also find for our subsample that greater firm leverage $(L E V)$ is assessed significantly lower audit fees ( $p$-value <0.05). Finally, we find that top-tier auditors $(B I G N)$, auditor detection of material misstatements (RESTATE), and the issuance of a modified going concern opinion $(G C)$ are associated with significantly higher audit fees ( $p$-value $<0.01)$, consistent with prior literature. The model explains $79.41 \%$ in the variation across firm years in audit fees and is significant at the $1 \%$ level.

Models 2 of Table 4 provide the results of regression analysis which assesses research question 1 by including our variable of interest (CEO_INVENT) and controlling for audit fee determinants used in Model 1. Once again, this analysis clusters standard errors by firm (GVKEY) and year and includes n-1 industry and year dichotomous variables. According to model 2 analysis, we find a positive and significant association between $C E O \_I N V E N T$ and audit fees ( $p$-value $\left.<0.01\right)$. This result suggests that auditors consider the presence of innovative CEOs as a priced risk factor that they incorporate into audit 
fees. This finding suggests that on average auditors dedicate more effort and/or assess a risk premium to firms with inventor CEOs, consistent with the argument presented above that these CEOs increase firm and auditor business risk. Specifically, auditor pricing of inventor CEOs may be driven by the CEO's "sensation-seeking", risk taking appetite which could result in over-investing in $\mathrm{R} \& \mathrm{D}$, all of which combined could result in higher firm failure rates.

\section{CEO Overconfidence}

\section{ADDITIONAL ANALYSIS}

Malmendier and Tate $(2005,2009)$ find that overconfident CEOs have higher investment-cash flow sensitivities and are more likely to engage in value-destroying mergers. We, therefore, assess auditors' response to the combined effect of CEOs owning patents and characterized as overconfident, and potentially aggressive in their pursuits of projects, and thus more willing to take on high levels of risk. In untabulated analysis, we regress the natural log of audit fees (LnAF) on the presence of CEO patents (CEO_INVENT), overconfident CEO (CEO_OVERCONF), and the interaction term (CEO_INVENT*CEO_OVERCONF), while controlling for audit fee determinants. The untabulated analysis finds a positive and significant association between audit fees and CEO_INVENT, consistent with Table 4 findings. We do not find a significant association between audit fees and CEO_OVERCONF nor do we find evidence of a significant increase in auditor pricing of $\left(C E O \_I N V E N T^{*} C E O \_O V E R C O N F\right)$. This suggests that our initial finding of a fee premium in the presence of inventor CEOs is not exacerbated by CEO overconfidence.

\section{Audit Risk}

According to Table 4 analysis and findings, we suggest that auditors charge a fee premium in the presence of inventor CEOs and this is attributed to business risk. To our knowledge, we find no research evidence to suggest that the presence of inventor CEOs is associated with audit risk. In an attempt to further understand the reasoning behind auditor pricing of CEO_INVENT, and assess whether the premium assessed on inventor CEO is also attributed to audit risk in addition to business risk, we assess whether auditors regard the presence of inventor CEO as an audit risk factor ${ }^{\mathrm{vii}}$. To do so, we assess whether inventor CEO firms are assigned significantly greater audit fees in the presence of greeter audit risk (CEO_INVENT*Audit_Risk). We use financial statement restatements (RESTATE) in Model 1 and the presence of a detected material weakness in internal controls over financial reporting $(I C W E A K)$ in model 2 of Table 5 as proxies for audit risk.

Table 5. The Audit Risk Effect

\begin{tabular}{|l|c|c|}
\hline & \multicolumn{2}{|c|}{ Dependent variable=LnAF } \\
\hline & Audit_Risk=RESTATE & Audit_Risk=ICWEAK \\
\hline Variables & Model (1) & Model (2) \\
\hline & Coefficient & Coefficient \\
\hline CEO_INVENT(1) & (t-statistic) & 0.073 \\
\hline & 0.075 & $(2.87)^{* * *}$ \\
\hline Audit_Risk(2) & $(2.94)^{* * *}$ & 0.281 \\
& 0.187 & $(6.47)^{* * *}$ \\
\hline$(1) *(2)$ & $(4.47)^{* * *}$ & 0.142 \\
& 0.085 & $(1.26)$ \\
\hline EControls & $(0.81)$ & YES \\
\hline
\end{tabular}




\begin{tabular}{|l|c|c|}
\hline Constant & 4.604 & 4.606 \\
\hline & $(37.92)^{* * *}$ & $(37.95)^{* * *}$ \\
\hline & & YES \\
\hline Industry FE & YES & YES \\
\hline Year FE & YES & 6,667 \\
\hline Observations & 6,667 & $79.44 \%$ \\
\hline R-squared & $79.44 \%$ & $561.05^{* * *}$ \\
\hline Model & $560.91 * * *$ & . \\
\hline
\end{tabular}

$*, * *$, and $* * *$ measure significance at the $10 \%, 5 \%$, and $1 \%$ levels, respectively. All regressions include year and industry fixed effects. Standard errors are robust and clustered at the firm and year levels (Peterson, 2009). The definitions of all variables are provided in Appendix A.

According to Table 5, we find a positive and significant association between audit fees and CEO_INVENT ( $p$-value $<0.01)$ and a positive and significant association between audit fees and Audit Risk (both proxies in Models 1 and 2). However, we do not find evidence of an increase in pricing of CEO_INVENT in the presence of audit risk (CEO_INVENT*Audit_Risk). This finding further suggests that the premium assigned on the presence of inventor CEO is more likely linked to auditor business risk and less so to audit risk, consistent with our arguments above.

\section{Audit Quality}

We also assess whether higher quality audits and monitoring are associated with mitigating some risks embedded in inventor CEOs. To assess this, we assess auditor pricing of the interaction of CEO_INVENT and Audit_Quality. This analysis is presented in Table 6. We rely on two proxies for audit quality, in Model 1 of Table 6 Panel B, we use the presence of top tier auditors $(B I G N)$ and in model 2 of the same table, we use auditor specialist (SPECIALIST) as the second audit quality proxy.

Table 6. The Audit Quality Effect

\begin{tabular}{|l|c|c|}
\hline & \multicolumn{2}{|c|}{ Dependent Variable=LnAF } \\
\hline & Audit_Quality=BIGN & Audit_Quality=SPECIALIST \\
\hline Variables & Model (1) & Model (2) \\
\hline & Coefficient & Coefficient \\
\hline & (t-statistics) & $(\mathrm{t}-$ statistics $)$ \\
\hline CEO_INVENT(1) & 0.245 & 0.077 \\
\hline & $(3.12)^{* * *}$ & $(3.09)^{* * *}$ \\
\hline Audit_Quality (2) & 0.123 & 0.347 \\
& $(3.73)^{* * *}$ & $(5.16)^{* * *}$ \\
\hline$(1) *(2)$ & -0.184 & -0.065 \\
& $(-2.24)^{* *}$ & $(-0.35)$ \\
\hline Controls & YES & YES \\
\hline Constant & 4.590 & 4.601 \\
\hline & $(37.76)^{* * *}$ & $(37.92)^{* * *}$ \\
\hline & & YES \\
\hline Industry FE & YES & YES \\
\hline Year FE & YES & 6,667 \\
\hline Observations & 6,667 & \\
\hline
\end{tabular}




\begin{tabular}{|l|c|c|}
\hline R-squared & $79.45 \%$ & $79.47 \%$ \\
\hline Model & $561.29 * * *$ & $552.53 * * *$ \\
\hline
\end{tabular}

$*, * *$, and $* * *$ measure significance at the $10 \%, 5 \%$, and $1 \%$ levels, respectively. All regressions include year and industry fixed effects. Standard errors are robust and clustered at the firm and year levels (Peterson, 2009). The definitions of all variables are provided in Appendix A.

In both models 1 and 2 of Table 6, we find that auditors charge significantly higher fees for CEO_INVENT and Audit_Quality (both BIGN and SPECIALIST). Furthermore, in Model 1 of the same table, we also find that the engagement of a top-tier auditor (BIGN) mitigates the risks embedded in CEO_INVENT, as evidenced by the negative and significant coefficient on the interaction term (CEO_INVENT*Audit_Quality). This finding does not hold when we substitute audit specialists for toptier auditor (model 2).

\section{Financial Distress}

Finally, we assess the effect of financial distress on the association between audit fees and the presence of an inventor CEO. Specifically, we assess whether auditors consider in their pricing decision whether innovative CEOs that are in pursuit of innovative projects during difficult times are regarded as risky from an auditors' perspective. We present this analysis in Table 7. Model 1 of Table 7 uses the issuance the auditor of a modified going concern opinion $(G C)$, suggesting that the auditor presumes that the firm will not be viable in the near future, as a proxy for distress and Model 2 uses the Altman score ${ }^{\text {viii }}$ as a measure of distress.

Table 7. The Effect of Financial Distress

\begin{tabular}{|l|c|c|}
\hline & \multicolumn{2}{|c|}{ Dependent Variable=LnAF } \\
\hline & DISTRESS=GC & DISTRESS=ASCORE \\
\hline Variables & Model $(1)$ & Model $(2)$ \\
\hline & Coefficient & Coefficient \\
\hline CEO_INVENT $(1)$ & (t-statistics) & $(\mathrm{t}$-statistics) \\
\hline & 0.067 & 0.143 \\
\hline DISTRESS $(2)$ & $(2.67)^{* *}$ & $(5.45)^{* * *}$ \\
& -0.070 & -0.000 \\
& $(-0.68)$ & $(-5.27)^{* * *}$ \\
\hline (1) $(2)$ & 0.470 & -0.010 \\
& $(2.73)^{* * *}$ & $(-7.12)^{* * *}$ \\
\hline Controls & YES & YES \\
\hline & 4.607 & $(37.529$ \\
\hline & $(37.96)^{* * *}$ & \\
\hline Industry FE & & YES \\
\hline Year FE & YES & YES \\
\hline Observations & YES & 6,659 \\
\hline R-squared & 6,667 & $79.60 \%$ \\
\hline Model & $79.46 \%$ & $574.20^{* * *}$ \\
\hline
\end{tabular}

$*, * *$, and $* * *$ measure significance at the $10 \%, 5 \%$, and $1 \%$ levels, respectively. All regressions include year and industry fixed effects. Standard errors are robust and clustered at the firm and year levels (Peterson, 2009). The definitions of all variables are provided in Appendix A. 
Regardless of the distress measure used, we find that auditors assign a significantly higher audit fee for CEO_INVENT ( $p$-value < 0.01), and the risks embedded in CEO_INVENT are exacerbated in the presence of firm distress $\left(C E O \_I N V E N T^{*} D I S T R E S S\right)$ (p-value $\left.<0.01\right)$. Specifically, the presence of a going concern opinion is associated with significantly higher audit fees for inventor CEO firm years $(\mathrm{p}$ value $<0.01$ ) in Model 1, whereas the greater the bankruptcy score (suggesting lower bankruptcy risk) results in a significant decrease in auditor pricing of innovative CEOs (CEO_INVENT*ASCORE) ( $p$ value $<0.01)$. The results of Table 7 suggest that auditors are more worried about business risks embedded in the presence of inventor CEOs.

\section{DISCUSSION}

We find evidence to suggest that auditors assign a fee premium in the presence of inventor CEOs. In other words, auditors approach an engagement with an innovative manager with skepticism given the many side effects from their pursuits of innovative breakthroughs. This finding contributes to and adds to the Upper Echelon Theory (by including an auditor perspective). Consistent with research and anecdotal evidence suggesting that the presence of inventor CEOs may increase firm business risk, we find evidence to suggest that auditors price this business risk. Our additional analysis further supports this conclusion. Specifically, we assess whether the presence of greater audit risk (restatements and internal control weaknesses) exacerbates the association between audit fees and the presence of an inventor CEO and find no significant moderating effect. Furthermore, also in additional analysis, we find that firm financial distress (a measure of business risk) exacerbates auditor pricing of inventor CEOs. This suggests that auditors are more worried about the CEO's innovative pursuits when the financial position of the firm is not amenable to these investments and in turn is more likely to result in firm failure (business risk).

We also find evidence to suggest that our results are not driven by overconfidence on behalf of the CEO, which in prior literature has been linked to greater business risks.

Finally, our additional analysis finds evidence to suggest that the fee premium assigned to firms with inventor CEOs is mitigated by the presence of top tier auditors. This finding may suggest that top tier auditors and their superior inside information of their audit client may be able to better assess the qualities of an inventor CEO, their surrounding environment, as well as their investment opportunities and reassess the riskiness of these CEO inventors. Furthermore, the presence of a top tier auditor may deter risk seeking inventor CEOs from pursuing projects that serve their personal interests at the expense of shareholders, thus reduce business risk.

Future research may investigate the characteristics of these inventor CEOs (e.g. education, risk appetite, aggressive pursuits of patents, their success rates of prior innovative attempts,..) and the influence that these characteristics have on managerial decision making and in turn auditor pricing. Furthermore, investigating the risk appetite of the firm and the industry and how they reflect on auditor pricing of innovative CEOs may yield insights on when these innovative pursuits align the interests of managers and shareholders and when it creates a moral hazard problem. Given our finding of an exacerbated premium on CEO innovation during financial difficulties, it would be of interest to academics and stakeholders to assess this association during periods of uncertainty (e.g the COVID global health pandemic period), when innovation was demanded by the general public and crucial to the adaptation of environmental changes, in efforts to overcome the adversity.

\section{REFERENCES}

Baranchuk, N., Kieschnick, R., \& Moussawi, R. (2014). Motivating innovation in newly public firms. Journal of Financial Economics, 111(3), 578-588. 
Bedard, J. C., \& M, J. K. (2004). Earnings manipulation risk, corporate governance risk, and auditors' planning and pricing decisions. The Accounting Review, 79(2), 277-304.

Bell, T. B., Landsman, W. R., \& Shackelford, D. A. (2001). Auditors' perceived business risk and audit fees: Analysis and evidence. Journal of Accounting Research, 39(1), 35-43.

Benabou, R., \& Tirole, J. (2003). Intrinsic and extrinsic motivation. Review of Economic Studies, 70(3), 489-520.

Bostan, I., \& Mian, G. (2019). Inventor Chief Executive Officers and Firm Innovation. International Review of Finance, 19(2).

Bradley, D., Gokkaya, S., \& Liu, X. I. (2017). Before an Analyst Becomes an Analyst: Does Industry Experience Matter? The Journal of Finance, 72(2), 751-792.

Byun, S. K., Fuller, K., \& Lin, Z. (2020). Should Firms Hire CEOs with Technical Expertise? April, 146.

Cai, Y., Sevilir, M., \& Tian, X. (2012). Do Entrepreneurs Make Good VCs? SSRN Electronic Journal. https://doi.org/10.2139/ssrn.2021327

Dickins, D. E., Higgs, J. L., \& Skantz, T. R. (2008). Estimating audit fees post-SOX. Current Issues in Auditing. Current Issues in Auditing, 2(1), A9-A18.

Glover, S. M., Jiambalvo, J., \& Kennedy, J. (2000). Analytical procedures and audit-planning decisions. Auditing: A Journal of Practice \& Theory, 19(2), 27-45.

Glover, S. M., Prawitt, D. F., J., S. J., \& F, Z. M. (2003). A test of changes in auditors' fraud-related planning judgments since the issuance of SAS no. 82. Auditing: A Journal of Practice \& Theory, 22(2), 237-251.

Gul, F., Chen, C., \& Tsui, R. (2003). Discretionary accounting accruals, managers' incentives and audit fees. Contemporary Accounting Research, 20(3), 441-464.

Hambrick, D. C., \& Mason, P. A. (1984). Upper Echelons: The Organization as a Reflection of Its Top Managers. The Academy of Management Review, 9(2), 193.

Hay, D. C., Knechel, W. R., \& Wong, N. (2006). Audit Fees: A Meta-analysis of the Effect of Supply and Demand Attributes*. Contemporary Accounting Research, 23(1), 141-191.

He, Z., \& Hirshleifer, D. (2020). The exploratory mindset and corporate innovation. Journal of Financial and Quantitative Analysis, 1-43.

Hitt, M. A., \& Ireland, R. D. (1985). Corporate Distinctive Competence, Strategy , Industry and Performance. Strategic Management Journal, 6(3), 273-293. 
Houston, R. W., F., P. M., \& H, P. J. (2005). Nonlitigation risk and pricing audit services. Auditing: A Journal of Practice \& Theory, 24(1), 37-53.

Hribar, P., Kim, J., Wilson, R., \& Yang, H. I.-H. (2013). Counterparty Responses to Managerial Overconfidence. SMU SOAR Accounting Symposium 2013, December 12-13. https://ink.library.smu.edu.sg/soa_research/1233

Huang, T. C., Huang, H. W., \& Lee, C. C. (2014). Corporate executive's gender and audit fees. Managerial Auditing Journal, 29(6), 527-547.

Islam, E., \& Zein, J. (2020). Inventor CEOs. Journal of Financial Economics, 135(2), 505-527.

Johnson, E. N., Kuhn, J. R., Apostolou, B. A., \& Hassell, J. M. (2013). Auditor perceptions of client narcissism as a fraud attitude risk factor. Auditing, 32(1), 203-219.

Judd, J. S., Olsen, K. J., \& Stekelberg, J. (2017). How do auditors respond to CEO narcissism? Evidence from external audit fees. Accounting Horizons, 31(4), 33-52.

Kannan, Y., Skantz, T., \& Higgs, J. (2014). The Impact of CEO and CFO Equity Incentives on Audit Scope and Perceived Risks as revealed through audit fees. Auditing: A Journal of Practice \& Theory, 33(2), 111-139.

Kerr, S. P., Kerr, W. R., \& Dalton, M. (2019). Risk attitudes and personality traits of entrepreneurs and venture team members. Proceedings of the National Academy of Sciences of the United States of America, 116(36), 17712-17716.

Li, G. C., Lai, R., D’Amour, A., Doolin, D. M., Sun, Y., Torvik, V. I., Yu, A. Z., \& Lee, F. (2014). Disambiguation and co-authorship networks of the U.S. patent inventor database (1975-2010). Research Policy, 43(6), 941-955.

Lyon, J. D., \& W, M. M. (2005). The importance of business risk in setting audit fees: Evidence from cases of client misconduct. Journal of Accounting Research, 43(1), 133-151.

Malmendier, U., \& Tate, G. (2009). Superstar CEO. Quarterly Journal of Economics, 124, 1593-1638.

Malmendier, U., \& Tate, G. (2005). CEO Overconfidence and Corporate Investment. Journal of Finance, 60(6), 2661-2700.

Matsunaga, S. R., Wang, S., \& Yeung, P. E. (2013). Does Appointing a Former CFO as CEO Influence a Firm's Financial Reporting, Disclosure and Tax Policies? SSRN Electronic Journal.

Palmrose, Z. V. (1997). Who got sued? Journal of Accountancy, 183(3), 67.

Peterson, M. (2009). Estimating standard errors in finance panel data sets: Comparing approaches. Review of Financial Studies, 22, 435-480. 
Raghunandan, K., \& Rama, D. V. (2006). SOX section 404 material weakness disclosures and audit fees. Auditing: A Journal of Practice \& Theory, 25(1), 99-114.

Simunic, D. (1980). The pricing of audit services: theory and evidence. Journal of Accounting Research, $18(1), 161-190$.

Stanley, J. D. (2011). Is the audit fee disclosure a leading indicator of clients' business risk? Auditing: A Journal of Practice and Theory, 30(3), 157-179.

Sunder, J., Sunder, S. V., \& Zhang, J. (2017). Pilot CEOs and corporate innovation. Journal of Financial Economics, 123(1), 209-224.

Walo, J. C. (1995). The effects of client characteristics on audit scope. Auditing: A Journal of Practice \& Theory, 14(1), 115-124.

Whisenant, S., Sankaraguruswamy, S., \& Raghunandan, K. (2003). Evidence on the joint determination of audit and non-audit fees. Journal of Accounting Research, 41(4), 721-744.

Zimbelman, M. F. (1997). The effect of SAS No. 82 on auditors' attention to fraud risk factors and audit planning decisions. Journal of Accounting Research, 35(supplement), 75-97.

\section{NOTES}

Note 1. Google reorganized as a subsidiary of a conglomerate (Alphabet Inc. which is a Fortune 500 firm).

Note 2. See Islam \& Zein (2020) and Bostan \& Mian (2019) for more examples.

Note 3. They measure financial risk by asking respondents "How much do you typically enjoy taking risks?" with a

follow-on asking specifically about financial risk.

Note 4. Counter to the findings of Byun et al, (2020), Islam \& Zein (2020) find a positive association between active inventor CEOs and total compensation.

Note 5. The MIT Centre for Entrepreneurship has made it mandatory that an inventor cannot be the founding CEO of a spin-off, see https://riccentre.ca/2009/09/the-imperativefor-non-inventor-ceos/.

Also see "Should the Inventor Be CEO? https://www.inventioncity.com/inventors/inventors-are-rarelygood-managers-and-ceos

Note 6. The literature finds evidence to suggest that financial expert CEOs improve financial reporting quality (Matsunaga, Wang, \& Yeung, 2013) increase profitability, and reduce failure rates (Custodio \& Metzger, 2014).

Note 7. Houston, Peters, \& Pratt (2005) characterize these risks as residual litigation and non-litigation risks, which encompass losses from damaged reputation, unpaid fees, and a reduction in future audit engagements. In general, auditors confront business risk from poorly performing clients (or clients where 
they anticipate poor performance in the future) in part, because they confront even non-meritorious litigation even if the audit is properly conducted (Palmrose, 1997). As noted by the US Department of the Treasury (2008), tort reform related to auditors acknowledges that they frequently face nonmeritorious litigation, even when audits are well planned and executed.

Note 8. An alternative explanation could be that inventor CEOs may have more incentives to manipulate financial performance when these externally funded and costly projects fail. This would suggest a heightened level of audit risk and even fraud risk, both of which have been associated with higher audit fees.

Note 9. We augment the Whisenant, Sankaraguruswamy, \& Raghunandan (2003) model with two indicator variables in Raghunandan and Rama (2006): ICFR to indicate whether the auditor provided an opinion on the client's internal control over financial reporting and ICWEAK to indicate if the firm had an adverse opinion on internal controls over financial reporting.

Note 10. The mean size-adjusted audit fees for the non-inventor CEO subsample is 1.749, whereas the mean for the inventor CEO subsample is 2.116 .

Note 11. Audit risk is "the risk that the auditor may unknowingly fail to appropriately modify his or her opinion in financial statements that are materially misstated" (AICPA, SAS 107, paragraph .02).

Note 12. The greater the Altman Z-score the lower the distress.

\section{APPENDICES}

\section{Appendix A: Variable Definitions}

\begin{tabular}{|l|l|}
\hline Variable & \multicolumn{1}{|c|}{ Definition } \\
\hline Dependent Variable & $\begin{array}{l}\text { The firm natural logarithm of the audit fees (AUDIT_FEES) at fiscal year- } \\
\text { end, from Audit Analytics }\end{array}$ \\
\hline Treatment Variable & $\begin{array}{l}\text { A dummy variable that identifies the CEOs who have at least one patent } \\
\text { filed during the sample period }\end{array}$ \\
\hline CEO_INVENT & \\
\hline $\begin{array}{l}\text { Audit Fee } \\
\text { Determinants }\end{array}$ & $\begin{array}{l}\text { The natural logarithm of total assets (AT) at fiscal year-end (in \$ millions), } \\
\text { from Compustat. }\end{array}$ \\
\hline LnTA & $\begin{array}{l}\text { 1 if firm i has foreign exchange gain or loss (FCA) at the end of the current } \\
\text { fiscal year, and 0 otherwise, from Compustat. }\end{array}$ \\
\hline FOROPS & $\begin{array}{l}\text { 1 if firm i reported extraordinary items or discontinued operations (XIDO) } \\
\text { in the current fiscal year, and 0 otherwise, from Compustat. }\end{array}$ \\
\hline XDOPS & $\begin{array}{l}\text { Inventory plus accounts receivable, divided by total assets [(RECT + } \\
\text { INVT)/AT] at fiscal year-end, from Compustat. }\end{array}$ \\
\hline INVREC &
\end{tabular}




\begin{tabular}{|c|c|}
\hline LAG & $\begin{array}{l}\text { The number of days between fiscal year end and earning reporting date } \\
\text { (RDQ), from Compustat. }\end{array}$ \\
\hline LOSS & $\begin{array}{l}1 \text { if firm i reports negative net income (NI) in the current or prior fiscal year, } \\
\text { and } 0 \text { otherwise, from Compustat. }\end{array}$ \\
\hline ROA & $\begin{array}{l}\text { Return on assets, defined as the ratio of operating income (OIADP) to fiscal } \\
\text { year-end total assets (AT) at fiscal year-end, from Compustat. }\end{array}$ \\
\hline LIQ & $\begin{array}{l}\text { The ratio of current assets (ACT) to current liabilities (ACL) at the current } \\
\text { fiscal year, from Compustat }\end{array}$ \\
\hline LEV & $\begin{array}{l}\text { The ratio of the sum of debt in current liabilities and long-term debt to total } \\
\text { assets [DLC+DLTT)/AT] at current fiscal year-end, from Compustat. }\end{array}$ \\
\hline MKTB & $\begin{array}{l}\text { The market value of the firm computed as the product of the fiscal year-end } \\
\text { share price and the number of shares outstanding at year-end, divided by } \\
\text { total assets at the end of the fiscal year (PRCC_F * CSHO)/AT. }\end{array}$ \\
\hline BUSY & 1 if firm $\mathrm{i}$ had fiscal year end $12 / 31$, and 0 otherwise. \\
\hline IO & $\begin{array}{l}\text { The percentage of institutional ownership at the beginning of the fiscal year, } \\
\text { from Compact the Disclosure database. }\end{array}$ \\
\hline BIGN & 1 if firm $\mathrm{i}$ auditor is a Big $\mathrm{N}$ auditor, and 0 otherwise, from Audit Analytics. \\
\hline SWITCH & $\begin{array}{l}1 \text { if the auditor is in the first year of an audit engagement in the current } \\
\text { fiscal year, and } 0 \text { otherwise, from Audit Analytics. }\end{array}$ \\
\hline RESTATE & $\begin{array}{l}1 \text { if a firm announced a restatement during the year, and } 0 \text { otherwise, from } \\
\text { Audit Analytics. }\end{array}$ \\
\hline GC & $\begin{array}{l}1 \text { if firm } \mathrm{i} \text { was issued a modified auditor going concern opinion in the } \\
\text { current fiscal year, and } 0 \text { otherwise, from Audit Analytics. }\end{array}$ \\
\hline ICWEAK & $\begin{array}{l}1 \text { if firm auditors identify a material weakness in internal control in the } \\
\text { current fiscal year, and } 0 \text { otherwise, from Audit Analytics. }\end{array}$ \\
\hline ICFR & $\begin{array}{l}1 \text { if firm i received an audit opinion on internal controls over its financial } \\
\text { (IC_IS_EFFECTIVE) in the current fiscal year, and } 0 \text { otherwise, from Audit } \\
\text { Analytics. }\end{array}$ \\
\hline
\end{tabular}

\section{Copyrights}

Copyright for this article is retained by the author(s), with first publication rights granted to the journal. This is an open-access article distributed under the terms and conditions of the Creative Commons Attribution license (http://creativecommons.org/licenses/by/4.0). 